\title{
Meta
}

Journal des traducteurs

Translators' Journal

\section{Hernández Guerrero, M. J. (2002): Marcel Schwob. Escritor y Traductor, Sevilla, Ediciones Alfar, 270 p.}

\section{Heberto Fernandez}

Volume 48, numéro 4, décembre 2003

URI : https://id.erudit.org/iderudit/008728ar

DOI : https://doi.org/10.7202/008728ar

Aller au sommaire du numéro

Éditeur(s)

Les Presses de l'Université de Montréal

ISSN

0026-0452 (imprimé)

1492-1421 (numérique)

Découvrir la revue

Citer ce compte rendu

Fernandez, H. (2003). Compte rendu de [Hernández Guerrero, M. J. (2002):

Marcel Schwob. Escritor y Traductor, Sevilla, Ediciones Alfar, 270 p.] Meta,

48(4), 588-589. https://doi.org/10.7202/008728ar

Ce document est protégé par la loi sur le droit d'auteur. L'utilisation des services d'Érudit (y compris la reproduction) est assujettie à sa politique d'utilisation que vous pouvez consulter en ligne.

https://apropos.erudit.org/fr/usagers/politique-dutilisation/
Cet article est diffusé et préservé par Érudit.

Érudit est un consortium interuniversitaire sans but lucratif composé de l’Université de Montréal, l'Université Laval et l'Université du Québec à Montréal. Il a pour mission la promotion et la valorisation de la recherche. https://www.erudit.org/fr/ 


\section{Comptes rendus}

Hernández Guerrero, M. J. (2002): Marcel Schwob. Escritor y Traductor, Sevilla, Ediciones Alfar, $270 \mathrm{p}$.

María José Hernández Guerrero is currently professor of translation at the University of Málaga, where she received her Ph.D. in Philology. She wrote her dissertation on Marcel Schwob, and since then has continued doing research on the work of this French writer. This book is the product of her continuous research on the subject, and its purpose is to present the figure of Marcel Schwob as a man of letters as well as a translator. The life and work of Marcel Schwob have attracted little attention from scholars until recent times, and so the book serves as an introduction to the subject, especially for the Spanish-speaking world, where Schwob still remains a rather unknown figure.

Besides an introduction and a conclusion, the book contains five chapters. The first chapter is biographical in nature: Hernández Guerrero describes the cultural environment where Schwob (1867-1905) grew up, focusing on his precocious interest in languages and literature, his life as a prolific artist and journalist, his fascination with the classics, and his erudition. From this exposition emerge the image of a versatile writer and scholar, who during his short life worked as a literary writer and critic, essayist, journalist, and translator. The author draws attention to a particular date in Schwob's life: the year 1895, when his health begins to deteriorate. That year is a true dividing line in the life of Marcel Schwob because it marks the end of his literary career and the beginning of his work as a translator.

In the following four chapters, Hernández Guerrero concentrates on two aspects of Schwob's multifaceted career: his work as a literary writer and, after 1895, as a translator. The approach to this subject is both chronological and descriptive.

Chapters Two and Three deal with Schwob's literary work. Chapter Two provides a social and cultural framework to Schwob's works of fiction. It is the author's thesis that, although Schwob has been traditionally classified as a symbolist writer, this point of view is misleading. In fact, Hernández Guerrero shows, first, that Schwob's early short stories show the influence of both symbolism and realism, but that he soon broke away from those tendencies and, second, that by his technique of grouping a series of short stories united by a subject or common denominator in a single volume, Schwob was really an avant-garde writer who paved the way for new narrative techniques in the 20th century. The third chapter supports this thesis by a more detailed analysis of the themes and structures of Schwob's main works: Coeur Double (1891), Le Roi au masque d'or (1892), Mimes (1893), Le Livre de Monelle (1894), Vies imaginaries (1896), and La Croisade des enfants (1896).

Chapter Four and Five develop in a similar way to the preceding two chapters: the former provide a social and cultural setting to Schwob's translations, while the latter present a more detailed analysis of his translations, in particular, Schwob's translation of Hamlet. In these two chapters, Hernández Guerrero describes the enormous influence of such English writers as Shakespeare, Defoe, Whitman, Poe and Stevenson on Schwob, and how this influence made Schwob devote his best efforts to the translation into French of English writers.

The author devotes particular attention to the study of Schwob's translations of Shakespeare's Hamlet and Defoe's Moll Flanders. From a theoretical point of view, Schwob was in favour of preserving as much as possible of the author's original form and style in his translations, using archaisms to cope with the time passed between the original and the 
translation. In the framework of the time-honored debate between style and content in literary translation, Hernández Guerrero discusses Schwob's principle, according to which "On ne saurait croire combine les expressions et les tournures ont d'analogie dans deux langues arrivées au même degré de formation" (p. 196), and surveys the opinions of diverse scholars on the aforementioned debate. For the author, Schwob's archaized translations still retain their value and are still in vogue, as shown by the fact that they continue to be reprinted nowadays.

Although repetitive at times, this is an interesting, easy to read, and well-documented introductory work. A comprehensive bibliography at the end of the book provides further reading for those interested in the subject.

Heberto Fernandez

Université de Montréal, Montréal, Canada

\section{Huang, Z. (2000): On Translation Variation (in Chinese), Beijing, China Translation and Publishing Corporation.}

The mainstream of translation, down through history, is translation pure and simple, which is called full or formal translation. But another important part of translation, translation variation, remains unstudied. It is noted that in the $21^{\text {st }}$ century, this main stream is becoming less dominant and giving way to translation variation because of copyright, and other factors.

We know at least something about translation variation, but translation circles, being interested in the "formal" ways of translation, have ignored its importance and regard it as "informal" or heterodox. Actually translation variation is not "new" at all. In translating foreign cultural thought, translation variation was and is used frequently, and will be used more in the future. However, most researchers do not pay close attention to it, and it needs further study.

On Translation Variation (hereafter referred to as TV) issues the challenge to develop a new field in translation research from a practical standpoint, i.e., stressing "how". TV's arguments are penetrating. It defines translation variation as an activity aimed at deriving the theme or partial contents of the original version by using the appropriate adaptations such as expansion, deletion, summarization, explanation, supplement, combination and reformation in the light of the special needs of the readers. If the full translation methods are regarded as the microcosmic ways, the translation variation is a macroscopic translation one. Full translation conveys the contents of information, but is restricted by the form of the information. Translation variation supplies a set of adaptive ways, giving translators free rein to their subjective initiatives. TV argues that it is translation variation that embodies the value of translation because for target readers the greatest value of translation is to absorb foreign cultures. Absorbing is not simply equal to full translation. It is hard to totally absorb the original version (foreign cultures), and sometimes unnecessary. It is only by adaptations that translators can capture the theme of the original and change it into their own. So far, translation variation meets the need for adaptations.

TV is creative. In the light of translation practices in history and at present, it sums up eleven translation varieties. They are selective translation, translation and editing, translated narration, condensed translation, translated summarization, summarized translation commentary, translated commentary, explanatory translation, translation rearrangement, translation and writing, and reference translation. And TV is sure that there will be more translation varieties in the future.

TV is well organized. It is composed of twelve chapters. Chapter One is the introduction to translation variation, and the other eleven chapters (2-12) probe into eleven transla- 